\title{
The Current Environmental Situation and Green Solutions for Vietnam's East Sea
}

\author{
Thi Minh Hao Dong, Huu Cuong Le, Thanh Hai Truong
}

\begin{abstract}
The South China Sea, including the Vietnam Sea, is witnessing significant changes under the impact of both nature and man. These are the impacts of climate change and ocean change with "extreme" signs such as increasing storms, coastal floods, sea level rise, sea acidification, pollution and environmental incidents, ... occur thicker, more intense and irregular. Especially serious degradation of the environment and biodiversity of the sea, increasing environmental incidents, including oil spills, ... due to human impact. Especially the large-scale destruction of coral reefs, seagrass beds in island clusters off the South China Sea has been happening at a worrying rate. The destructive fishing activities of humans in the South China Sea have caused ecosystem degradation and the extinction of some species, such as sea turtles, some sharks and another species. Other fish, especially the giant mussel, the consequence is a decrease in the natural capital of the sea, leading too prolonged "ecological disturbances". The reserves of seafood in the Spratly region (of Vietnam) and the West Sea in the East Sea have decreased by about $19 \%$ compared to before 2017. Therefore, the improvement of marine environment quality, including biodiversity conservation and major marine ecosystems are to preserve marine natural assets, contributing to the implementation of Vietnam's green growth strategy and action plan. This is the path that Vietnam has chosen to both grow marine economy, adapt to climate change, and protect the environment both in the short and long term, towards sustainable development.
\end{abstract}

Index Terms-East Sea, South China Sea, Climate Change, Environmental Pollution of Sea.

\section{INTRODUCTION}

The sea and ocean (hereinafter referred to as the sea for short) are considered to be rich in natural resources, have an important geostrategic position, and are a living space for mankind and a place for living competition of the world's leading economies. The total value of marine natural capital is estimated to be at least 24,000 billion USD and annual marine product (GMP) - equivalent to the nation's gross domestic product (GDP) - at least 2.5 trillion VND[1]. Around the world, about 3 billion people have marinedependent livelihoods and marine resources contribute to economies above $5 \%$ of global GDP[2]. Clearly, the future of mankind is highly dependent on the sea, especially when the global population exceeds 7 billion and the land resources are exhausted and polluted[3].

In a transitional and globalized world with a particularly important role of the sea and ocean, interdependence is more evident than ever. Globalization affects countries and regions, whereas the proper development and efficiency of a

Published on September 15, 2019

Thi Minh Hao Dong, Huu Cuong Le, Thanh Hai Truong are with Ho Chi Minh city University of Transport, Ho Chi Minh city, Vietnam. country will contribute significantly to global issues. In Vietnam, restructuring the economy associated with renewing the growth model towards efficiency and sustainability is one of the top key tasks[4]. This is a good opportunity for Vietnam to move towards the blue sea economy, blue growth and sustainable development. Therefore, on September 25, 2012, the Prime Minister issued Decision No. 1393 / QD-TTg approving the national strategy on green growth and the national action plan on increasing Green growth period 2014-2020 in Decision No. 403 / QD-TTg March 20, 2014.

East Sea, a semi-enclosed sea surrounded by most of ASEAN countries and China. Geographical location is critical for both countries in and outside the region and for the international community as a whole. In addition, the South China Sea is also a high-value marine area in terms of resources and environment, on marine conservation towards a blue-sea economy[5]. However, the South China Sea is facing increasing challenges in terms of environment, marine resources, safety and maritime security related to negative human behaviors[6]. It can be seen that the overexploitation of marine resources, the increase in acts of environmental destruction, the loss of ecosystems in and around the coral islands cluster off the East Sea, the risk of waste disposal, landfill of all kinds of waste, etc. has been happening with worrying speed. This has a negative impact on the environment and ecology of the East Sea and consequently has a direct impact on human life and the development of nations in the region[7].

Therefore, protecting the marine environment, conserving bio-diversity and marine ecosystems, and preserving the natural capital of the sea towards a green East Sea is an urgent practical need. This is the way for countries in the region to develop an effective and sustainable maritime economy, contributing to building a peaceful and stable sea.

\section{VIETNAM MARINE ENVIRONMENTAL ISSUES IN THE SOUTH CHINA SEA CONTEXT}

The Vietnam Sea is a part of the South China Sea, with an area of 3 times the land area (accounting for about $29 \%$ of the South China Sea), including: waters within 200 nautical miles, continental shelf (with 2 areas extending up to 350 nautical miles) and two clusters of Hoang Sa and Truong Sa islands[8]. With a wide sea area, long coastline (over 3,260 $\mathrm{km}$ ) and many islands (over 3,000 large and small islands), Vietnam attaches great importance to the special role of the marine economy[9], associating efficient and sustainable development of the marine economy with the country's strategy of protecting sea and island sovereignty[10].

Over the past time, Vietnam's marine economy has made 
important contributions to the country's economy, but the development scale up to now is not commensurate with its potential and is being alarmed at a high level. Especially serious degradation of the environment and marine biodiversity, increasing environmental incidents, ... due to negative human behaviors. Especially recently China has destroyed large-scale coral reefs and sea grass beds to expand and the construction of artificial islands on coral reef shoals in clusters of islands off the Spratly and Paracel islands at a worrying rate[11].

In addition, the destructive fishing activities of people in the South China Sea have caused the degradation of ecosystems and the danger of extinction of some rare and precious marine species, which threaten the fisheries of Vietnam and other countries in the region[12].

Therefore, to develop a fast, efficient and sustainable marine economy, more than ever, Vietnam needs to turn to green solutions[13]. This is not only a need but also a right strategic choice. Only then will Vietnam be able to become a nation "strengthened from the sea and enriched from the sea" as the overall goal of the Vietnam Sea Strategy to 2020 has been set (Party Central Executive Committee, Course X, 2007). In other words, Vietnam must gradually eliminate "brown" solutions that pollute the environment to apply "green" solutions to ensure environmental security, guarantee Vietnam's sovereignty over marine resources in accordance with national and international laws.

Offshore reef systems are a key feature of the South China Sea, developed on the basis of ancient volcanic rock with geographic features such as islets (usually less than 1 $\mathrm{km} 2$ ), rocks, shallow shoals and shallow water in the reefs. Coral reefs are the most important and most vulnerable ecosystem in the ocean and the sea[13]. They are "Common home" of about 3,000 species of creatures in the South China Sea. In particular, the South China Sea, around the Spratly archipelago and extending to the coast of the island of Luzon (Philippines), Brunei and Khanh Hoa-Ninh Thuan (Vietnam) is home to the highest coral diversity (about 517). species). It is close to the coral species diversity (566 species) of the International Coral Triangle, centered on Indonesian and Philippine waters[13].

Not only a common house, offshore reefs also provide nutrients, sources of seafood seeds and larvae of shrimp, fish, ... for the rest of the South China Sea due to the presence of a strong, variable seasonal surface flow system. As a result, the South China Sea has high biodiversity and conservation value, rich and abundant aquatic resources. The United Nations Environment Program (UNEP) asserts that the South China Sea accounts for $1 / 10$ of the world's total fish catch, and by 2030, China will account for $40 \%$ of global fish consumption. According to the evaluation of De Groot et al. (2012) the total economic value of one hectare of coral reef is US \$ 350 thousand per year[14]. This shows that protecting the marine environment and ecosystems of offshore reefs will ensure environmental security and aquatic resources throughout the East Sea.

The aforementioned islands (coral clusters) of offshore islands, which contain intertwined strategic interests of nations in and outside the South China Sea, have been in the sights of the great powers[15]. With unilateral claims and unjustified claims of the "nine-dashed line" (also known as the U-shaped line) occupying more than $80 \%$ of the entire South China Sea, China has gradually illegally occupied the whole. Paracel island cluster (1974) and over 7 shoals in the Spratly island group of Vietnam (1988 and 1995)[16]. More seriously, recent unilateral claims and actions to improve the shoals into China's artificial islands are threatening the environment and ecological security in the South China Sea.

In addition, Vietnam's marine environment is facing challenges from its development activities, both at sea and on land, of which the impacts from the land resources are remarkable[17]. The concentration of marine pollutants in Vietnam, in general, tends to increase, in seawater, mainly manifested by organic substances, nitrate, grease, TSS. This trend is evident in seabed sediments due to an increase in the ability to accumulate pollutants of sustainable toxicity in the marine environment such as heavy metals, durable organic compounds (POPs). Pollution of organic substances, heavy metals and oil appears "locally" related to the activities of fishermen at sea, in ports, fishing wharves and coastal industrial areas[18].

However, the amount of waste dumped into the sea is increasing and increasing in coastal waters and is constantly increasing over the years. Synonymous with the sea of our country is increasingly being "poisoned" by environmental incidents and the consequences will be "unpredictable". The amount of solid waste generated in the coastal area in 2009 was 14.03 million tons (in 2009); oil is about 35,160 tons / day, nitrogen total 26 - 52 tons / day and total ammonium 15 - 30 tons / day (2010). Coastal tourism activities alone produce 32,273 tons of waste and $4,817,000 \mathrm{~m}^{3}$ of wastewater a year. With a total area of shrimp farming more than 600 thousand hectares in 2003, each year will release nearly 3 million tons of solid waste into the environment[19]. Particularly, the amount of waste in coastal provinces: solid waste 5,200 - 10,300 tons / day, wastewater of 11.8 million tons / day and grease $150-440$ tons / day (Vietnam General Department of Sea and Islands, 2011).

Oil spills also tend to increase, involving even international maritime activities through the South China Sea unsafe in the context of tensions over sovereignty over islands and islands. Particularly in Vietnam's waters, from 1989 to 2009, there were recorded over 100 oil spills due to ship accidents[20], each of which poured into the sea from several tens to hundreds of tons of oil[5], causing significant impacts on the economy. and environment. "Unknown source" of oil sludge continues to occur, sometimes on a large scale and causing great economic and marine damage such as the 2007 unknown oil spill in 22 provinces from Ha Tinh to Kien Giang [21]. Transboundary environmental issues are also of interest, such as cross-border pollution due to plant protection chemicals in the mouth of the Bac Luan estuary (bordering China) and between the Tonkin Gulf.

The management of the amount of waste discharged into the sea from economic zones, industrial parks and coastal export processing zones is showing weakness and coastal environmental incidents occur frequently at different scales. Typically, the incident of discharging into the sea in April 2016 of Taiwan Hung Nghiep Steel Company (Formosa) in Vung Ang Economic Zone (Ha Tinh) has serious consequences for 4 coastal provinces in the North Central 
Coast (Ha Tinh, Quang Binh, Quang Tri and Thua ThienHue) due to coastal pollution and degradation of nearly $50 \%$ of the coral reef area due to Phenol and Xianua, massive fish deaths.

\section{THE EFFICIENCY OF DAMAGE OF THE EAST SEA ENVIRONMENT}

Professor Gomez from the Institute of Marine Science, University of the Philippines said that "In a rush to gain control of the South China Sea, the Chinese government and military leadership seem to have little or no interest in the fact that coral reefs and seagrass beds, and shallow marine ecosystems in the South China Sea are rapidly being destroyed and buried" [22]. So far, China has not only expanded about 1,500 hectares of "artificial islands" from the shoals of the Spratly and Paracel Islands, but also destroying thousands of hectares of coral reefs, seagrass beds and other shallow marine ecosystems for use as such embellishment materials into such "artificial islands". This action has caused serious damage to the countries along the East Sea, including China itself with an estimated amount of 4 billion dollars per year [6]. China has expanded, embellished and destroyed coral reefs in the Spratly island group about 99\%, Vietnam, Malaysia, Philippines and Taiwan accounted for $1 \%$. This means that China is responsible for about $99 \%$ of all damage from activities in coral reefs in the South China Sea [23]. If China does not stop mining and deposition of shallow beaches, the damage will continue to increase.

These practices of China not only alter the inherent natural structure and function of the shoals, rocks and reefs of the Spratly Islands, but "severing" the ecological linkage between these islands and the rest of the South China Sea. This has a wider impact on the ability to provide nutrition, seed sources and aquatic resources for much of the South China Sea and adjacent waters of the countries in this maritime area. Vietnamese, Filipinos, Malaysians, Indonesians and even the Chinese themselves will suffer. GS. John McManus (University of Miami, USA) warns, "We are headed for a major disruption in fisheries and this environmental disaster will affect the lives of millions of people [24]. Time to take action now".

In addition, the destructive fishing activities of Chinese fishermen in the South China Sea area have caused the degradation of the ecosystem and the extinction of some species, such as sea turtles, some sharks and another fish species, especially the giant mussel. The reserves of seafood in the Spratly island group and the western part of the South China Sea in Vietnam have decreased by $16 \%$ compared to before 2010. Destruction of giant clam populations in the Hoang Nham shoals (occupied by the Philippines since the end of 2012) plus the exploitation of large amounts of biological shells from the shoal surface leading to prolonged "ecological" disturbances, destroying many species of benthos, ... Such shells are delicately carved, sold to tourists and locals in Hainan, China[25]. In addition, the number of coral reefs and fish species in disputed waters in the South China Sea has decreased from 460 to 261 and the current list of endangered species includes green turtles, giant calamus mussels and tortoises.
As such, China has seriously violated relevant international conventions, such as: UNCLOS (articles 60, $192,193,196)$, especially article 208 on pollution of marine environment; Convention on Biological Diversity (CBD); The Convention on International Trade in Endangered Species of Fauna and Flora (CITES) and in violation of Article 6 of the Declaration on the Conduct of Parties in the South China Sea (DOC) have been committed by China itself. Actions that stand on international law, disrespect for bilateral commitments, and with ASEAN thus have met with a strong international response. However, China has still blatantly expanded the construction of "artificial islands" in the Spratly and Paracel island clusters, increasing tensions in the South China Sea. The changing situation of the East Sea has led to the trend of "internationalizing" this maritime area even though China does not want it [26].

The level of environmental impact and violation of the aforementioned laws of the Chinese side was established and announced in Annex VII of UNCLOS by the Arbitration Court and officially announced on the afternoon of July 12, 2016. Accordingly, the Supreme Court Tai found that "China has seriously harmed the coral reefs' environment and violated its duty to conserve and protect vulnerable ecosystems, and habitat of weakened, threatened and extinct species. At the same time, the Chinese authorities are aware of the fact that Chinese fishermen have been catching large and rare marine turtles, corals and mussels in the South China Sea, and has failed to fulfill its obligations to prevent and terminate these activities[27]. The Court also found that China's recent large-scale artificial island accretion and construction are inconsistent with UNCLOS member states' obligations in the process of resolving disputes, insofar as China has caused irreparable harm to the marine environment, built a large artificial island within the exclusive economic zone of the Philippines, and destroy evidence of the natural conditions of structures in the South China Sea that are part of a dispute between the parties "(Permanent Court of Arbitration, 2016: personal information).

Vietnam is also a country strongly affected by climate change (climate change) and sea level rise (NBD). Calculated from actual observation data at three stations Hon Dau (Hai Phong), Son Tra (Da Nang) and Vung Tau (Ba Ria - Vung Tau) shows that, in the past 50 years, the average sea level has risen $3-4 \mathrm{~mm} /$ year, that is, nearly half of the last century, the sea level in Vietnam has risen about $15-20 \mathrm{~cm}$ [22]. The three SLR scenarios of the Ministry of Natural Resources and Environment (2012) show different levels of SLR in coastal Vietnam.

If NBD is $1 \mathrm{~m}$, there will be about $39 \%$ of the Mekong Delta area (Mekong Delta), over 10\% of the Red River Delta (RRD) area, and Quang Ninh, over $2.5 \%$ of the central coastal provinces and over $20 \%$ of Ho Chi Minh City are at risk of flooding[28]. Nearly 35\% of the Mekong Delta's population, over 9\% of the Red River Delta and Quang Ninh's population, nearly $9 \%$ of the population in the Central Coastal provinces and about $7 \%$ of the city's population. Ho Chi Minh City is directly affected (Ministry of Natural Resources and Environment, 2012) [29].

At the atoll clusters off the South China Sea, due to the average elevation of the islands low, for example in the 
Spratly island cluster the average elevation is only $2.3 \mathrm{~m}$ above sea level. Therefore, NBD will cause most of the area of such island clusters to be submerged under the sea. Climate change also causes extreme weather events, with strong impacts on coastal areas and islands, resulting in environmental incidents and pollution.

\section{DEMAND FOR GREEN SOLUTIONS}

The discharge of flue gas from diesel The abovementioned practices in the East Sea and Vietnam Sea have shown that the general trend of environmental evolution and factors of marine resources is the foundation of sustainable development and blue growth in our country. This raises the need for solutions to abandon the "old habit" and to adopt a new habit - blue solutions. According to GS. Gunter Pauli: "Deep ecology - a philosophical tendency that A. Naess represents - views humanity as an integral part of nature and thinks that the environment also has the right to live and develop. Human development, along with sustainability, are the original seeded concepts of blue thinking "[30].

In order to improve the marine environment, restore degraded marine-coastal resource systems and maintain the natural marine resources according to the aforementioned green thinking, green solutions need to be applied. The Vietnam Sea Strategy to 2020 has defined the relationship between marine economic development and the protection of the marine environment and marine resources (Central Committee of the Communist Party, 10th term, 2007). Next, the national strategy on green growth to 2020, vision to 2030 (possibly called the green strategy) (Government, 2012) and the national action plan for the period of 20142020 on green growth (Government) Government, 2014) pointed out that: "Green growth is based on increasing investment in conservation, development and efficient use of natural capital, reducing greenhouse gas emissions, and improving environmental quality. thereby stimulating economic growth." The Green Strategy also sets out a common goal: "Green growth, moving towards low-carbon economies, enriching natural capital becomes the key trend in sustainable economic development; reducing emissions and increasing the absorption of greenhouse gases gradually become a mandatory and important indicator in socioeconomic development".

The above-mentioned Environmental Judgment of the Arbitration Tribunal provides international legal principles to the countries concerned in the South China Sea region and other relevant parties, environmental organizations around the world and in The Department struggles with environmental damage to the East Sea environment and enhances cooperation to apply green solutions. Although China continues to pursue the principle of "three no" - not participating in the lawsuit, not acknowledging and not executing the decision of the Arbitral Tribunal, but the negative impact on the marine environment will affect China itself.

So far, domestic and international scholars have proposed various solutions to ask China to comply with the environmental decision in the South China Sea. and the Asian-American Institute) argue that overfishing and increasing destruction of coral reefs require scientific-based policy intervention (Borton, 2016). He proposed that "given the increasing number of collisions between fishing vessels in disputed areas, ASEAN leaders should probably find a way to reduce the number of such incidents, instead of resorting to sending more ships." the field, ... at the same time establishing the Regional Marine Science Council to handle environmental degradation issues, promote dialogue to establish a peaceful marine park in the South China Sea, propose a regional scientific subcommittee to consider the Antarctic Treaty as a model for the South China Sea."

Stakeholders and China should consider some confidence-building measures by promoting the implementation of Article 6 of the Declaration on the Conduct of Parties in the South China Sea (DOC) (DOC, 2002). Expanding scientific cooperation among ASEAN marine scientists; Independent scientific investigation in disputed areas, artificial islands are an objective practical need. In the immediate future, it is advisable to focus on existing solutions and initiatives, such as project implementation (phase II) on "Implementation of strategic action plan to combat environmental degradation in the East Sea" in the period of 2017-2020. and "establishing a network of Marine Protected Areas (MPAs) in the South China Sea region based on the existing MPA system of Vietnam, the Philippines", Research "Establishing a marine park pacific - Peace Marine Park" in the Spratly Island cluster area as suggested by John McManus (1989, 1994).

In addition, consideration should be given to the establishment of clusters of atolls off the coast of a number of "Biodiversity and ecologically important waters" (EBSA) for management under the provisions of the International Convention on Biodiversity (CBD, 1994). Some of the areas with high potential and high marine conservation value but at risk of risks of international maritime activities should be established as "Particularly environmentally important waters" (PSSA) for management within the framework of the MARPOL Convention of the International Maritime Organization (IMO). Take advantage of and take advantage of Asia-Pacific initiatives in efforts to mitigate and adapt to climate change, disaster risk management, within the framework of the Intergovernmental Commission on Oceanography of the Western Pacific Region (IOC WESPAC).

In coastal areas of our country, in addition to strengthening the management of marine protected areas under the planning already approved by the Prime Minister, the system of new marine protected areas should be expanded, prioritizing the restoration of coastal ecosystems such as mangroves, seagrass beds, coastal wetlands and coastal coral reefs through the Government's programs / projects. Government and international organizations, including the Mangrove Initiative for the Future (MFF). In particular, it is necessary to improve the system of policies, laws, inter-sectoral coordination mechanisms and technical processes, to effectively control waste and pollution sources from the mainland to the sea and waste on coastal islands.

\section{CONCLUSION}

The South China Sea and Vietnam Sea are facing many global and regional environmental issues, especially 
environmental issues arising from the negative human behaviors of offshore atoll clusters and illegal fishing activities in overlapping waters for sovereignty ambitions.

The environmental impact of such challenges is clear, causing serious harm in the short and long term, as determined by The Hague Arbitration Court. Expanding and constructing shallow beaches into artificial islands in the Spratly island cluster will not only change the legal position of the shallow beaches, but also destroy the environment of the East Sea.

To solve environmental problems in the East Sea, priority should be given to the selection of green, adaptive, and ecosystem-based solutions. Regional cooperation under judgment can only be effectively implemented when stakeholders build strategic trust, sit at the negotiating table, and be transparent with information, and effective coordination through scientific cooperation on green solutions.

In terms of awareness, it is necessary to educate about the sovereignty for the whole society not only about territorial sovereignty over Vietnam's seas and islands in the South China Sea, but also about Vietnam's sovereignty over its own marine resources and the duty to protect the marine environment over its territorial waters and sovereign rights.

\section{REFERENCES}

[1] Y. Huang and P. T. Vuong, "Fisheries cooperation and management mechanisms in the South China Sea: context, limitations, and prospects for the future," Chinese J. Comp. Law, vol. 4, no. 1, pp. 128-148, 2016.

[2] F. Lasserre, "Maritime borders in the South China Sea: Dynamics of claims and legal basis," in Assessing Maritime Disputes in East Asia, Routledge, 2017, pp. 122-140.

[3] J. Wang, "Marine Protected Areas Network in the South China Sea: Charting a Course for Future Cooperation, written by Vu Hai Dang," Int. J. Mar. Coast. Law, vol. 32, no. 2, pp. 373-377, 2017.

[4] N. T. N. Bach, "The building of artificial islands of China in the Spratly Islands-An analysis in the viewpoint of the international law," Sci. Technol. Dev. J., vol. 19, no. 2, pp. 77-90, 2016.

[5] A. T. Hoang, "A report of the oil spill recovery and treatment technologies to reduce the marine environment pollution," Int. J. $e$ Navigation Marit. Econ., vol. 9, pp. 35-49, 2018.

[6] L. M. Campbell et al., "Global oceans governance: New and emerging issues," Annu. Rev. Environ. Resour., vol. 41, pp. 517-543, 2016.

[7] M. Barbesgaard, "Blue growth: savior or ocean grabbing?," $J$. Peasant Stud., vol. 45, no. 1, pp. 130-149, 2018.

[8] N. Hedberg, N. Kautsky, M. Hellström, and M. Tedengren, "Spatial correlation and potential conflicts between sea cage farms and coral reefs in South East Asia," Aquaculture, vol. 448, pp. 418-426, 2015.

[9] A. T. Hoang and V. V. Pham, "A review on fuels used for marine diesel engines," J. Mech. Eng. Res. Dev., vol. 41, no. 4, pp. 22-32, 2018 .
[10] T. D. Thanh, M. D. Fortes, and N. Miyazaki, "National coordination of the JSPS Coastal Marine Science Program in Vietnam," 2016.

[11] T. Q. Nguyen, "Research and Development for Oil Spill Simulation Backward in Time at East Vietnam Sea," J Pet Env. Biotechnol, vol. 8, no. 344, p. 2, 2017.

[12] X. Sun, Q. Li, M. Zhu, J. Liang, S. Zheng, and Y. Zhao, "Ingestion of microplastics by natural zooplankton groups in the northern South China Sea," Mar. Pollut. Bull., vol. 115, no. 1-2, pp. 217-224, 2017.

[13] A. T. Hoang and V. V. Pham, "A study of emission characteristic, deposits, and lubrication oil degradation of a diesel engine running on preheated vegetable oil and diesel oil," Energy Sources, Part A Recover. Util. Environ. Eff., vol. 41, no. 5, pp. 611-625, 2019.

[14] T.-D. Truong and K. Knio, "The United Nations Convention on the Law of the Sea (UNCLOS III) and China's Assertion of the U-shaped Line," in The South China Sea and Asian Regionalism, Springer, 2016, pp. 61-83.

[15] A. T. Hoang and V. V. Pham, "Impact of jatropha oil on engine performance, emission characteristics, deposit formation, and lubricating oil degradation," Combust. Sci. Technol., vol. 191, no. 03, pp. 504-519, 2019.

[16] D. Huang et al., "Extraordinary diversity of reef corals in the South China Sea," Mar. Biodivers., vol. 45, no. 2, pp. 157-168, 2015

[17] P. H. Hoang, A. T. Hoang, N. H. Chung, L. Q. Dien, X. P. Nguyen, and X. D. Pham, "The efficient lignocellulose-based sorbent for oil spill treatment from polyurethane and agricultural residue of Vietnam," Energy Sources, Part A Recover. Util. Environ. Eff., vol. 40, no. 3, pp. 312-319, 2018.

[18] X. P. Nguyen, "The bus transportation issue and people satisfaction with public transport in Ho Chi Minh city," J. Mech. Eng. Res. Dev., 2019.

[19] A. T. Hoang, "Waste heat recovery from diesel engines based on Organic Rankine Cycle,” Appl. Energy, vol. 231, pp. 138-166, 2018.

[20] A. T. Hoang, V. V Pham, and D. N. Nguyen, "A report of oil spill recovery technologies," Int. J. Appl. Eng. Res., vol. 13, no. 7, pp. 4915-4928, 2018

[21] A. T. Hoang et al., "An absorption capacity investigation of new absorbent based on polyurethane foams and rice straw for oil spill cleanup," Pet. Sci. Technol., vol. 36, no. 5, 2018.

[22] A. Smajgl et al., "Responding to rising sea levels in the Mekong Delta," Nat. Clim. Chang., 2015.

[23] F. Lasserre, "8 Maritime borders in the South China Sea," Assess. Marit. Disput. East Asia Polit. Leg. Perspect., p. 122, 2017.

[24] N. Hong, "Exploring maritime dispute management in the South China Sea: A practical approach," in Assessing Maritime Disputes in East Asia, Routledge, 2017, pp. 141-167.

[25] O. Hoegh-Guldberg, "Reviving the Ocean Economy: the case for action," 2015

[26] S. W. Smith, "ASEAN, China, and the South China Sea: Between a Rock and a Low-Tide Elevation," USF Mar. LJ, vol. 29, p. 29, 2016.

[27] A. R. Maggio, "Regional cooperation for protection of the marine environment in Southeast Asia: current trends in the South China Sea," Asia Pacific J. Environ. Law, vol. 22, no. 1, pp. 160-170, 2019.

[28] M. N. Islam and N. Q. Hung, "Climate Change Impacts on Marine Ecosystems in Vietnam," in Environmental Management of Marine Ecosystems, 2018.

[29] L. E. Erban, S. M. Gorelick, and H. A. Zebker, "Groundwater extraction, land subsidence, and sea-level rise in the Mekong Delta, Vietnam," Environ. Res. Lett., 2014.

[30] G. Pauli, "From Deep Ecology to The Blue Economy," Blue Econ. 2011. 